\title{
A Consideration on Emotional Labour, Burnout Syndrome and Job Performance: The Case of Health Institutions
}

\author{
Vural Çağlıyan \\ Selçuk University, School of Tourism and Hospitality Management, Konya/Turkey. \\ vcagliyan@selcuk.edu.tr \\ Mehtap Fındık \\ Res. Ass., Selçuk University, Faculty of Economics and Administration Sciences, \\ Department of Business Administration, Konya/Turkey. \\ mehtapfindik@selcuk.edu.tr

\section{Burcu Doğanalp} \\ Res. Ass. Dr., Selçuk University, Faculty of Economics and Administration Sciences, \\ Department of Business Administration, Konya/Turkey. \\ burcudoganalp@selcuk.edu.tr
}

Doi:10.5901/mjss.2013.v4n10p532

\begin{abstract}
The aim of this study is to examine the relationship between emotional labour which is defined as workers' exhibiting appropriate emotions designated by the organization towards the customers of the organization, and burnout syndrome and job performance. Accordingly, a field research based on survey method was conducted on the employees of a health institution operating in the province of Konya. As a result of the research, statistically significant relationship was found between emotional labour and burnout. In addition, it was found that job performance was decreasing as burnout levels were increasing and there was a statistically significant relationship between emotional labour level and job performance of workers. In addition, it was determined that there was a statistically significant relationship between the level of emotional labor and job performance of the employees.
\end{abstract}

Keywords: Emotional Labour, Burnout Syndrome, Task Performance, Contextual Performance.

\section{Introduction}

In the service sector, where the relationships with customer were intensively experienced, in providing the customer satisfaction, the effort the employees emotionally and mentally spent has importance as much as the one they emotionally spent in terms of the quality of work performed. In the frame of this understanding, in business life, like physical effort, also emotional effort the employees exerted has been begun to be seen as a value and the concept of emotional labor, seen as marketable value in exchange of wage, has emerged (Hochschild, 1983: 7). Especially, in health sector, where face to face relationships are experienced in high level, in terms of patient satisfaction, patients should exert the emotional labor in high level. Besides the emotional labor, exerted in high level, can positively affect the organizational outcomes such as improving job performance and job satisfaction, it negatively affects the organizational outcomes such as burnout. Therefore, in the study, the relationships between emotional labor, burnout, and job performance will be examine.

\section{Conceptual Framework}

\subsection{Emotional Labor}

The concept of emotional labor is first used by Hochschild (1979) with the expression of emotional work. In 1983, in the book called "The Managed Heart" by Hochschild, this concept first time was defined as motional labor and began to 
develop. Hochschild (1983: 7) defined the emotional labor as making an indication facially and physically, as a requirement of job, arranging the emotions in such a way that they can be seen by the others, When regarding to the studies carried out, emotional labor was generally expressed as "the action to exhibit the appropriate emotions" (Ashforth and Humphrey, 1993: 90) or "the forms of efforts, planning, and supervision needed to express the organizationally desired emotions across the process of sustaining interpersonal relationships" (Morris and Feldman, 1996: 987; Grandey, 2000: 97 ).

When the literature of emotional labor is examined, there are some different views about the dimensions of emotional labor, but it is seen that this is generally considered under three dimensions as deep acting, surface acting (Grandey, 2000; Brotheridge and Grandey, 2002; Diefendorf et al. 2005), and genuine emotion (Ashforth and Humprey, 1993). Deep acting is the controlling process of employee his/her emotions and thoughts as a requirement of indication rules (Brotheridge and Grandey, 2002: 22). Surface acting is that employees, in the frame of the institutional and professional indication rules, fixing their emotions, reflect them on the customer or receiver in different way from the emotions they actually feel (Hochschild, 1983; Brotheridge and Grandey, 2002: 22; Basım and Begenirbaş, 2012: 79). And genuine emotions are expressed that the employee reflects out his/her emotions inherently (Basım and Begenirbaş, 2012: 79). In this context, in this study, emotional labor was considered in three dimensions as deep acting, surface acting, and genuine emotions (Basım and Begenirbaş; 2012).

\subsection{Burnout Syndrome}

Burnout is a concept first considered in the clinical studies by Freudenberger (1974). Freudenberger (1974: 159) defines the burnout "as a state of being exhausted in the internal resources of individual as a result of being unsuccessful, wearing out, losing energy and power, and unsatisfied desires" (Budak and Sürgevil, 2005: 96). With that Maslach (1982) considered the burnout syndrome as a social problem (Maslach and Goldberg, 1998: 64), since it reflected the real experiences of people in business life, it became a concept that is begun to be examined in the organizational literature. From this point of view, burnout syndrome is defined as a long termed reaction against the chronic, emotional, and interpersonal stress resources in business environment (Maslach and Goldberg, 1998: 64).The exhaustion behavior in the business environment emerge in three forms as emotional exhaustion, depersonalization, and reduced personal accomplishment (Maslach and Jackson, 1981: 99; Maslach and Goldberg, 1998: 64). Emotional exhaustion is defined as exhaustion of individual's emotions and feelings toward the other people (Leiter and Maslach, 1988: 297; Bruce, 2009: 58, Yıldırım and İçerli, 2010:124). Depersonalization is defined as that the individual feels lack of emotion toward the people (Bruce, 2009: 58); his/her negative and inflexible attitudes toward the people he/she serves; that he/she becomes unreactive to the job (Budak and Sürgevil, 2005: 96); and that he/she behaves to the people like an object, says insolent words to the people, exhibits an indifferent and mocker attitude (Yıldırım and İçerli, 2010: 124). Reduced personal accomplishment represents the dimension of evaluating the own achievement of person and it means the decrease at the level of the sufficiency and efficiency in the business of individual (Maslach and Goldberg, 1998: 64).

\subsection{Job Performance}

Job performance can be qualified as total of individual performances in different organizational sections realized in a standard time interval (Edwards et al., 2008: 444) Job performance is generally conceptualized as behaviors and actions making contribution to the aims of organization and being in the control of individual (Johnson and Maede, 2010: 1). From this aspect, job performance, in which the aim, target and beliefs are shaped by task demands within the organization, is defined as a multidimensional structure (Befort and Hattrup, 2003: 17). In the literature, it is seen that job performance is generally considered in two dimensions as task and contextual performance (Motowidlo and Van Scotter, 1994). Task performance states the basic responsibilities that points out the technical core of organization; distinguishes the tasks within organization from each other (Edwards et al., 2008: 444); and has to perform the task (Onay, 2011: 590). Contextual performance considers the organizational, social, and psychological environment providing support in the technical environment of organization (Motowidlo and Van Scotter, 1994: 476). The contextual performance is behaviors including the activities such as that the employee, who provides information to the culture and climate of organization, has information about the rules and procedures of organization; helps to the other people in the organization; contributes to the organizational instruments; and exerts extra effort for completing the task (Befort and Hattrup, 2003: 17). In this context, it can be said that task performance is a concept associated with performing a task determined within 
organization, while contextual performance includes the voluntary behaviors to support the organizational achievement (Onay, 2011: 590)

\subsection{Relationships between Emotional Labor, Burnout and Job Performance}

Emotional labor has social and psychological effects on the employees. One of the psychological effects of emotional labor is burnout (Larson and Yao, 2005: 1103). In the studies carried out. Burnout was evaluated as an outcome of emotional labor (Morris and Feldman, 1996). Similarly, Grandey (2000), in the study he carried out, considered burnout as an outcome of emotional labor. In the study, in case that the emotional participation of employees is high in the relationships with customer, it was put forward that burnout will emerge. Brotheridge and Grandey (2002), in the study they carried out, they determined that there was a positive relationship between the dimensions of emotional exhaustion and depersonalization of burnout and the dimensions of deep and surface acting of emotional labor. However, while it was determined that there was a negative relationship between reduced personal achievement and surface acting, it was determined that there was a positive relationship between deep acting. Kim (2008), in the study he carried out, while he determined a positive relationship between surface acting, considered the sub-dimension of emotion labor, and emotional exhaustion and depersonalization, considered as sub-dimensions of burnout, he put forward that there was a negative relationship reduced personal achievement and surface acting. While a positive relationship was determined between the behavior of deep acting and emotional exhaustion and personal achievement, a negative relationship was determined between depersonalization and emotional labor. When the relationship between emotional labor and job performance was examined, Ünlü and Yürür (2011), in the study they carried out, determined that there was a positive relationship between emotional labor and job performance. Onay (2011), in his study, while he determined a positive relationship between task performance and surface acting and deep acting, he concluded that there was a negative relationship between contextual performance and surface acting

\section{Research Methodology}

In this section of the study, information will be given about the aim, hypotheses, and findings of study realized by using the method of survey. In addition, whether or not the results obtained in the study were statistically significant will be assessed and whether or not the hypotheses are confirmed will be tested.

\subsection{Method of Study and Sample}

In forming the dataset of this study, method of survey was utilized from the method of survey, the study was carried out on the employees of a health institute (since the institute did not permit about publishing its name, in the study, the expression of health institute took place) being in active in the province Konya. In the studies, the data were collected by means of standard questionnaire prepared by regarding to likert scale and via face to face interviews conducted with the responders. The items in the scale were put in order in the form " $1=$ I definitely disagree" and " $5=$ I definitely agree". In the study, in determining the points to be included in the sample, convenience sampling method, used in the similar studies (Cui et al., 2003; Zhou, 2004), was chosen. Convenience sampling, since it provided the possibility to rapidly access to a number of dates, was a preferred method (Nakip, 2003).

In calculating the sample size, Yazıcıoğlu and Erdoğan (2004: 50) were utilized. The authors, for confidentiality value $\alpha=0.05$ with equation error ${ }_{+}-0.05$, and in the condition that the rate of being observed and not being observed of each $x$ variable in the universe is accepted equal, in case of having a sample size of 500 people, calculated the number of survey that should be conducted as 217 . In this context, the rate of survey that should be returned is approximately $44 \%$. In the health institution, where the study was carried out, 280 health personnel work and as a result of application made, 128 questionnaires, suitable to asses, were obtained. The return rate, obtained in this context, is approximately $45 \%$ and it can be said that this represents the main body.

\subsection{The aim and Hypotheses of the Study}

The aim of study is to determine the levels of emotional labor, burnout, and job performance of the employees of a health institute being in active in a heath sector in the province Konya and to examine the relationships between the levels of emotional labor, burnout, and job performance. In the direction of this aim, the hypotheses developed in the scope of 
study were put in order as follows.

Hypothesis 1: "There is a statistically significant relationship between the level of emotional labor and burnout emotion of health staff".

Hypothesis 2: "There is a statistically significant relationship between the level of emotional labor and job performance of health staff".

\subsection{The Scales Used in the Study}

In the study, in order to determine the levels of emotional labor of the employees of health institute, "Scale of Emotional Labor", including some items of emotional labor scales by Grandey (2000) and Kruml ve Geddes (2000), developed by Diefendorff et al. (2005), and adapted to Turkish by Basım and Begenirbaş (2012 was used; in order to measure the level of burnout, "Scale of Burnout", developed by Maslach and Jackson (1981) and adapted to Turkish by Ergin (1992); and in order to determine the levels of job performance, "Scale of Job Performance" Borman and Motowidlo (1993), Borman et al. (1995) and Motowidlo and Van Scotter (1994) used in their studies.

\section{The Findings of Study}

\subsection{Specifications of sample}

$65.9 \%$ of those participating in the study is male, and $34.1 \%$ female. The mean age of participants is about 35 and the youngest participator is 24 years old and the oldest participator is 58 years old. The academic titles of participants are: 42.1\% Asst Dr., 9.5\% specialist doctor, 20.6\% Asst. Prof. Dr., 17.5\% Assoc .Prof. Dr. and 10.3\% Prof. Dr. 48.3\% of participants are working on internal medicine, $44.2 \%$ on surgical medicine, and $7.5 \%$ on basic medicine.

\subsection{The Findings about Emotional Labor}

In order to determine the levels of emotional labor of those participating in the study, the items taking place in Table 1 were asked in the form of 5-point likert scale. In the scale, 1 is in the meaning of "disagreeing at all" and 5 is in the meaning of agreeing in very high level. The results are seen as follows:

Table1. The level of Emotional Labor

\begin{tabular}{|c|c|c|}
\hline Scale of Emotional Labor & Mean & SD \\
\hline While I am engaged in the patients, I pretend to feel myself well. & 2,22 & 1,29 \\
\hline In order to be able to exhibit the emotions my profession requires, I pretend to take on a masque. & 2,23 & 1,22 \\
\hline While I am engaged in the patients, as if I am making a show, I exhibit an extra performance. & 2,04 & 1,22 \\
\hline I play act for being able to be interested in the patients appropriately & 1,97 & 1,15 \\
\hline While I am performing my profession, I behave as if I feel the emotions I do not feel & 2,23 & 1,21 \\
\hline I exhibit the different emotions other than those I actually feel to the patients. & 2,27 & 1,20 \\
\hline Surface Acting & 12,77 & 6,13 \\
\hline I exert effort to also actually feel the emotions I have to show & 2,90 & 1,41 \\
\hline I try to actually experience the emotions I have to show to the patients & 3,04 & 1,32 \\
\hline I show an intensive effort in order to be able to feel inside of me & 2,61 & 1,32 \\
\hline In order to be able to feel the emotions I have to show to the patients, I do everything as much as possible & 2,96 & 1,34 \\
\hline Deep Acting & 11,27 & 4,21 \\
\hline The emotions I showed to the patents spontaneously reveal. & 3,63 & 1,08 \\
\hline The emotions I exhibit to the patients are friendly & 3,89 & 1,00 \\
\hline The emotions I showed to the patients is the same as those I felt at that moment. & 3,58 & 1,13 \\
\hline While I am engaged in the patients, I show false emotions. & 1,98 & 1,14 \\
\hline Genuine Emotions & 12,95 & 2,41 \\
\hline General Total $^{*}$ & 37,55 & 7,92 \\
\hline
\end{tabular}

\footnotetext{
* Cronbach's alpha values of the variables examined after added points related to variables. Cronbach's alpha value of the scale is 0,719 . The Cronbach's alpha values show that the scale was highly reliability and possible to use total score by related to item scores of variables.
} 
Notes: (i) $n=113$, (ii) in the scale, I is in the meaning of "I definitely disagree" and 5 , in the meaning of "I definitely agree" (iii). According to two way Anova Test of Friedman, $X^{2}=636,045 ; p<0,001$; the results are statistically significant.

When Table 1 is examined, it can be said that the answers of participants associated with each dimension predominantly range in the low level. In other words, the level of emotional labor is low. While the scores of the dimension of surface acting and deep acting are at low level in the context of scale, genuine emotions is higher compared to the other two dimensions in the context of scale. This case can be evaluated in such a way that employees reflect their genuine emotions to their patients in the working environment.

\subsection{Findings about Burnout Emotion}

In order to determine the levels of burnout of those participating in the study, the items taking place in Table 2 were asked in the form of 5-point likert scale. In the scale, 1 is in the meaning of "disagreeing at all" and 5 is in the meaning of agreeing in very high level. The results are seen as follows:

Table2. Scale of Burnout

\begin{tabular}{|l|c|c|}
\hline Scale of Burnout & Mean & SD \\
\hline I feel that I am alienated to my job. & 2,47 & 1,31 \\
\hline I feel myself emotionally exhausted after return from the job. & 2,82 & 1,33 \\
\hline When I wake up in the morning, I cannot bear to this more & 2,39 & 1,21 \\
\hline Striving with the people having problem is really back-breaking & 3,14 & 1,31 \\
\hline I feel being sick of the work I do & 2,70 & 1,34 \\
\hline I think that my job constrained me & 2,81 & 1,43 \\
\hline I think that I work too much on my job. & 3,07 & 1,35 \\
\hline Directly working with people is creating stress on me. & 2,79 & 1,04 \\
\hline I feel that I reach at the end of the way & 2,28 & 1,32 \\
\hline Emotional Exhaustion & $\mathbf{2 4 , 5 9}$ & $\mathbf{7 , 7 8}$ \\
\hline As a necessity of my job, I feel that the people I meet behave as if they are not human being. & 2,32 & 1,18 \\
\hline Since I have begun to work on this job, I became harder against the people. & 3,00 & 1,37 \\
\hline I am afraid that this job increasingly made me solid. & 2,74 & 1,22 \\
\hline As a necessity of my job, I do not care what the people I meet are. & 2,14 & 1,32 \\
\hline As a necessity of my job, I feel that the people. I meet behave as if I have created the problems they meet. & 3,14 & 1,16 \\
\hline Depersonalization & 13,26 & 4,08 \\
\hline As a necessity of job, I immediately recognize what the people I meet feel. & 3,35 & 1,06 \\
\hline As a necessity of my job, I find the most appropriate solution ways for the problems of the people I meet. & 3,69 & 0,99 \\
\hline Thanks to job I carry out, I believe that I make a contribution to the life of people. & 3,81 & 1,09 \\
\hline I have a power to be able to do a lot of thing. & 3,40 & 1,24 \\
\hline As a necessity of my job, I create a comfortable atmosphere among the people I meet. & 3,41 & 0,98 \\
\hline After a close work with the people, I feel myself stimulated. & 3,15 & 0,97 \\
\hline I obtained a lot of considerable success on this work. & 3,22 & 1,21 \\
\hline In my job, I approach to emotional problems in unruffled way & 3,36 & 1,13 \\
\hline Reduced Personal Achievement & $\mathbf{2 6 , 6 6}$ & $\mathbf{5 , 2 2}$ \\
\hline Total ${ }^{*}$ & $\mathbf{6 5 , 2 2}$ & $\mathbf{1 1 , 7 2}$ \\
\hline
\end{tabular}

Notes: (i) $n=107$, (ii) in the scale, I is in the meaning of "I definitely disagree" and 5 , in the meaning of "I definitely agree" (iii). According to two way Anova Test of Friedman, $X^{2}=638,976 ; p<0,001$; the results are statistically significant.

When Table 2 is examined, it can be said that the answers of participants associated with each dimension predominantly range in the low level. In other words, the level of burnout of the participants is low. The scores of the dimension of emotional exhaustion and depersonalization are lower in the context of scale compared to the dimension of

\footnotetext{
* Cronbach's alpha values of the variables examined after added points related to variables. Cronbach's alpha value of the scale is 0,800 . The Cronbach's alpha values show that the scale was highly reliability and possible to use total score by related to item scores of variables.
} 
reduced personal achievement. When the results in the table are generally evaluated, it can be put forward that the employees perceived burnout as reduced personal achievement.

\subsection{Findings about Job Performance}

In order to determine the levels of job performance of those participating in the study, the items taking place in Table 3 were asked in the form of 5-point likert scale. In the scale, 1 is in the meaning of "disagreeing at all" and 5 is in the meaning of agreeing in very high level. The results are seen as follows:

Table5. Job Performance of Employees

\begin{tabular}{|l|c|c|}
\hline Scale of Job Performance & Mean & SD \\
\hline I think that my professional knowledge is enough & 3,88 & 1,10 \\
\hline I think that I am skillful in performing my job. & 4,17 & 0,87 \\
\hline I think that my professional abilities are adequate. & 4,02 & 0,92 \\
\hline I think that I am quick in performing my job. & 4,06 & 0,85 \\
\hline Task Performance & 15,83 & 3,88 \\
\hline I think that I am interested to my job. & 4,06 & 0,99 \\
\hline I think that I like the hospital. & 3,92 & 1,04 \\
\hline I think that I am interested and helpful to the patients. & 4,12 & 0,81 \\
\hline I think that my affiliation and respect to the patients are adequate. & 4,18 & 0,82 \\
\hline I think that I have care and attention in performing my job. & 4,16 & 0,93 \\
\hline I think that I work with my workmate in harmony and cooperation. & 4,20 & 0,93 \\
\hline I think that my respect and obedience are full to my superiors. & 4,14 & 0,98 \\
\hline I think that I am very glad about my job. & 3,99 & 1,09 \\
\hline I think that I am honest and trustworthy. & 4,31 & 0,82 \\
\hline I think that I work cleanly and tidily. & 4,18 & 0,89 \\
\hline I think that I am kind and cheerful. & 4,13 & 0,87 \\
\hline I think that I fit to the health rules. & 4,34 & 0,70 \\
\hline I think that I am friendly and helpful. & 4,31 & 0,82 \\
\hline I think that I am patient. & 4,15 & 0,83 \\
\hline I think that I have understanding and tolerance & 4,20 & 0,92 \\
\hline I think that I am resolved. & 4,19 & 0,94 \\
\hline I think that I am energetic and sympathetic & 4,05 & 1,01 \\
\hline I think that I can decide on my own about my job. & 4,10 & 0,98 \\
\hline I think that I have responsibility emotion. & 4,29 & 0,81 \\
\hline I think that my social relationships are positive. & 4,07 & 0,91 \\
\hline Contextual Performance & $\mathbf{8 1 , 3 0}$ & 16,22 \\
\hline General Total * & 99,23 & 14,42 \\
\hline
\end{tabular}

Notes: (i) $n=119$, (ii) in the scale, I is in the meaning of "I definitely disagree" and 5 , in the meaning of "I definitely agree" (iii). According to two way Anova Test of Friedman, $X^{2}=632,303 ; p<0,001$; the results are statistically significant.

It is seen that job performances of the participants in the context of scale are higher in general meaning. In the context, the dimensions of contextual performance are at higher level compared to the task performance. This situation can be evaluated in such a way that the working environment and objective conditions forming this environment are positively perceived.

\subsection{Hypotheses of Study}

The evaluation about hypotheses developed in the context of study will be done in this section the first hypothesis of this

\footnotetext{
* Cronbach's alpha values of the variables examined after added points related to variables. Cronbach's alpha value of the scale is 0,943 . The Cronbach's alpha values show that the scale was highly reliability and possible to use total score by related to item scores of variables.
} 
study is to scrutinize whether or not there is a relationship between the level of emotional labor and burnout emotion of health staff. In order to evaluate this situation, the correlation level between the dimensions forming the scales was regarded and the level of relationship was calculated by using Pearson correlation coefficient (Table 6).

Table 6. Correlation Matrix for Level of Emotional Labor and Level of Burnout

\begin{tabular}{|c|c|c|c|c|c|c|c|c|}
\hline & $\begin{array}{l}\text { Surface } \\
\text { Acting }\end{array}$ & $\begin{array}{l}\text { Deep } \\
\text { Acting }\end{array}$ & \begin{tabular}{|c|} 
Genuine \\
Emotions
\end{tabular} & $\begin{array}{c}\text { Emotional } \\
\text { labor }\end{array}$ & \begin{tabular}{|c|} 
Emotional \\
Burnout
\end{tabular} & \begin{tabular}{|c|} 
Depersona \\
lization
\end{tabular} & $\begin{array}{c}\text { Reduced Personal } \\
\text { Achievement }\end{array}$ & Burnout \\
\hline Surface Acting & 1 & & & & & & & \\
\hline Deep Acting & ,234(*) & 1 & & & & & & \\
\hline Genuine Emotions &,$- 379(* \star)$ & $-0,051$ & 1 & & & & & \\
\hline Emotional Labor &, $794(* *)$ &, $\left.708^{(* *}\right)$ & $-0,016$ & 1 & & & & \\
\hline Emotional Exhaustion & ,435(**) &, $196(*)$ &,$- 211\left(^{*}\right)$ &, $382(* \star)$ & 1 & & & \\
\hline Depersonalization & ,488(**) &, $226(*)$ &,$- 223\left(^{*}\right)$ &, $\left.436{ }^{* *}\right)$ &, $722(* \star)$ & 1 & & \\
\hline $\begin{array}{l}\text { Reduced Personal } \\
\text { Achievement }\end{array}$ & $-0,168$ & 0,063 &, $235(* *)$ & $-0,025$ & $-0,106$ &,$- 206\left(^{*}\right)$ & 1 & \\
\hline Burnout & $3900^{(*)}$ & $2411^{(*)}$ & $-0,115$ & ,401(**) & ,882(**) & ,748(**) & 309 (**) & 1 \\
\hline
\end{tabular}

Note: ${ }^{*} p<.001,{ }^{*} p<.05$

As seen in correlation matrix in Table 6, there are different situations in correlational relationships between the dimensions forming the scale. There is a positive direction and statistically significant relationship between the dimensions of emotional exhaustion and depersonalization and surface acting, while there is a negative direction and statically significant between reduced personal achievement. There is a negative directional and statistically significant relationship between emotional exhaustion and depersonalization and genuine emotions, while there is a positive directional and statically significant relationship between reduced personal achievement. When regarded in general meaning, there is a positive directional and statistically significant relationship between burnout emotion and the level of emotional labor. In the context of these results, Hypothesis 1 putting forward that there is a statistically significant relationship between the level of emotional labor and burnout emotion of health staff was accepted.

In the second hypothesis of this study, it is put forward that there is a relationship between the level of emotional labor and job performance of health staff. In order to evaluate this situation, the correlation level between the dimensions forming the scales was regarded and the level of relationship was calculated by using Pearson correlation coefficient (Table 7).

Table7: Correlation matrix for the level of emotional labor and job performance

\begin{tabular}{|c|c|c|c|c|c|c|c|}
\hline & $\begin{array}{l}\text { Surface } \\
\text { Acting }\end{array}$ & $\begin{array}{l}\text { Deep } \\
\text { Acting }\end{array}$ & $\begin{array}{l}\text { Genuine } \\
\text { emotions }\end{array}$ & $\begin{array}{c}\text { Emotional } \\
\text { Labor }\end{array}$ & $\begin{array}{c}\text { Task } \\
\text { Performance }\end{array}$ & $\begin{array}{l}\text { Contextual } \\
\text { Conference }\end{array}$ & $\begin{array}{c}\text { Job } \\
\text { Performance }\end{array}$ \\
\hline Surface Acting & 1 & & & & & & \\
\hline Deep Acting & $0,234^{* *}$ & 1 & & & & & \\
\hline Genuine Emotions & $-0,379^{* *}$ &,- 051 & 1 & & & & \\
\hline Emotional Labor & $0,794^{\star \star}$ &, $708^{(* *}$ &,- 016 & 1 & & & \\
\hline Task Performance & $-0,140$ &,- 036 & 097 &,- 099 & 1 & & \\
\hline $\begin{array}{l}\text { Contextual } \\
\text { Performance }\end{array}$ & $-0,385^{\star \star}$ & ,023 & ,238(**) &,$- 217\left(^{\star}\right)$ & ,623(**) & 1 & \\
\hline Job Performance & $-0,360^{* \star}$ & 012 & $224\left(^{*}\right)$ &,$- 206\left(^{*}\right)$ &, $741(* *)$ & ,987(**) & 1 \\
\hline
\end{tabular}

Note: ${ }^{* \star} p<.001,{ }^{*} p<.05$

As seen in correlation matrix in Table 7, there are different situations in the correlation relationships between the dimensions forming the scale. There is a negative directional relationship the task performance and contextual performance and surface acting. There are a negative directional relationship between task performance and deep acting, while there is a positive directional relationship contextual performance and deep acting. There is positive directional and statistically significant relationship between task performance and genuine emotions. When regarded in general meaning, between the level of emotional labor and job performance there is a negative directional and 
statistically significant relationship. In the context of these results, hypothesis 2 putting forward that there is a statistically significant relationship between the level of emotional labor and labor performance was accepted.

\section{Conclusion}

In this study, the relationships between the emotional labor and burnout levels and job performance of the employees of health institute were scrutinized. According to the results of the study, it was determined that while the levels of emotional labor of the employees were in the middle level, their levels of burnout are low and their job performance is in high level. The emotional labor was assessed in three sub- dimensions and it was determined that there was statistically significant relationship between these sub-dimensions and burnout, also assessed in three sub-dimensions. It was concluded that between emotional exhaustion and depersonalization and genuine emotions, there was a negative directional and statistically significant relationship, that while between reduced personal achievement, there was a relationship positive directional and statistically significant. When the relationship between emotional labor and job performance was examined, according to the results of study, it was determined that there was a statistically significant relationship between the level of emotional labor, and job performance of health staff. In addition, in the scope of study, it was identified that the levels of emotional labor of the individuals working in health institute affected their levels of burnout and job performance. This conclusion has a quality supporting the studies carried out in the literature (Larson and Yao, 2005; Morris and Feldman, 1996; Grandey, 2000; Kim, 2008; Ünlü and Yürür, 2011; Onay, 2011). In this context, that the further studies, due to some limitation in health sector, are carried out in the different sector in different sample size can be suggested in terms of generalizability of study. Let's make this explanation different slightly.

\section{References}

Ahforth, B.E., Humphrey, R.H.(1993). Emotional Labor in Service Roles The Influence of Identity" Academy of Management Review, Vol.18, 88-115.

Basim, N., Begenirbaş, M. (2012). Çalışma Yaşamında Duygusal Emek: Bir Ölçek Uyarlama Çalışması, Yönetim ve Ekonomi Dergisi, Cilt:19 Sayı:1, 77-90.

Befort, N., Hattrup, K. (2003). Valuing Task and Contextual Performance: Experience, Job Roles, and Ratings of the Importance of Job Behaviors, Applied H.R.M. Research, Vol. 8, No. 1, 17-32.

Borman, W. C., Motowidlo, S. J. (1993). Expanding the Criterion Domain to Include Elements of Contextual Performance, Personnel Selection in Organizations, New York: Jossey-Bass.

Borman, W. C., White , L. A., Dorsey, D. W. (1995). Effects of Rate Task Performance and Interpersonal Factors on Supervisor and Peer Performance Ratings, Journal of Applied Psychology, Vol.80, 168-177.

Brotheridge, C.M., Grandey, A.A. (2002). Emotional Labor and Burnout: Comparing Two Perspectives of "People Work", Journal of Vocational Behavior, 60, 17-39.

Bruce, S.P. (2009). Recognizing Stress and Avoiding Burnout, Currents in Pharmacy Teaching and Learning, Vol. 1, 57-64.

Budak, G., Sürgevil, O. (2005). Tükenmişlik ve Tükenmişliği Etkileyen Örgütsel Faktörlerin Analizine Illişkin Akademik Personel Üzerinde Bir Uygulama, D.E.Ü.I.I.B.F. Dergisi, Cilt: 20, Sayl: 2, 95-108.

Cui, C.C., Lewis, B.R., Park, W. (2003).Service Quality Measurement in The Banking Sector in South Korea, International Journal of Bank Marketing, 21(4), 191-201.

Diefendorff, J.M., Croyle, M.H., R.H. Grosserand (2005). The Dimensionality and Antecedents of Emotinal Labor Strategies, Journal of Vocational Behavior, Vol. 66, 339-357.

Edwards, B.D., Bell, S.T. (2008). Relationships between Facets of Job Satisfaction and Task and Contextual Performance, Applied Psychology: An International Review, Vol. 57, No.3, 441-465.

Ergin, C. (1992). Doktor ve Hemşirelerde Tükenmişlik ve Maslach Tükenmişlik Ölçeğinin Uyarlanması, R.Bayraktar, İ. DAĞ (Ed.), VII. Ulusal Psikoloji Kongresi Bilimsel Çalışmaları, Ankara, 143-154.

Freudenberger, H. J. (1974). Staff Burn-Out, Journal of Social Issues, Vol.30, No.1,159-165.

Grandey, A.A. (2000). Emotional Regulation in the Workplace: A New Way to Conceptualize Emotional Labor, Journal of Occupational Health Psychology, 5 (1), 95-110.

Hochschild, A.R. (1983). The Managed Hearth: Commercialization of Human Feeling, Berkeley: University of California Press.

Johnson, E.C., Meade, A.W. (2010). A Multi-Level Investigation of Overall Job Performance Ratings, 25th Annual Meeting of the Society for Industrial and Organizational Psychology, Atlanta, GA.

Kim, H.J. (2008). Hotel Service Providers' Emotional Labor: The Antecedents and Effects on Burnout, International Journal of Hospitality Management, 27, 151-161.

Kruml, S.M. ve D. Geddes (2000). Exploring The Dimensins of Emotional Labor:The Heart of Hoschshild's Work, Management Comunication Quarterly, Vol.14, 8-49. 
Larson, E., Yao, X. (2005). Clinical Empathy as Emotional Labor in the Patient-Physician Relationship, Journal of American Medical Association, 293 (9), 1100-1106.

Leiter, M.P., Maslach, C. (1988). The Impact of Interpersonal Environment on Burnout and Organizational Commitment, Journal of Organizational Behavior, Vol. 9, 297-308.

Maslach, C., Goldberg, J. (1998). Prevention of Burnout: New Perspectives, Applied \& Preventive Psychology, Vol. 7, $63-74$.

Maslach, C., Jackson, S.E. (1981). The Measurement of Experienced Burnout, Journal Of Occupational Behaviour, Vol. 2, 99-113.

Morris, J.A., Feldman, D.C. (1996). The Dimensions, Antecedents and Consequences of Emotional Labor, Academy of Management Review, Vol. 21, No.4, 986-1010.

Motowidlo , S. J., Van Scotter, J.R. (1994). Evidence that Task Performance Should Be Distinguished from Contextual Performance, Journal of Applied Psychology, Vol.79, No.4, 475-480.

Nakip, M. (2003). Pazarlama Araştırmaları Teknikler ve (SPSS Destekli) Uygulamalar, Seçkin Yayıncılık, Ankara.

Onay, M. (2011). Çalışanın Sahip Olduğu Duygusal Zekasının ve Duygusal Emeğinin, Görev Performansı ve Bağlamsal Performans Üzerindeki Etkisi, Ege Academic Review, 11 (4), 587-600.

Ünlü, O., Yürür, S. (2011). Duygusal Emek, Duygusal Tükenme ve Görev/ Bağlamsal Performans İlişkisi: Yalova'da Hizmet Sektörü Çalışanları İle Bir Araştırma, Erciyes Üniversitesi İktisadi ve Idari Bilimler Fakültesi Dergisi, 37, 183-207.

Yazicioğlu, Y., Erdoğan, S. (2004). SPSS Uygulamalı Bilimsel Araştırma Yöntemleri, Detay Yayıncılık, Ankara.

Yildirim, M. H., İçerli, L. (2010). Tükenmişlik Sendromu: Maslach Ve Kopenhag Tükenmişlik Ölçeklerinin Karşılaştırmalı Analizi, Organizasyon ve Yönetim Bilimleri Dergisi, Vol. 2, No. 1, ISSN: 1309 -8039, 123-131.

Zhou, L. (2004). A Dimension-Specific Analysis of Performance only Measurement of Service Quality and Satisfaction in China's Retail Banking, Journal of Services Marketing, 18(7), 534-546. 